\title{
Cost of IIIness Diabetes Melitus Tipe 2 dan Komplikasinya pada Peserta Jaminan Kesehatan Nasional (JKN) di Rawat Jalan Rumah Sakit Condong Catur Yogyakarta
}

\section{Cost of Illness Type 2 Diabetes Mellitus and Its Complications in National Health Insurance at Outpatient Condong Catur Hospital Yogyakarta}

\author{
Rr. Erni Kusuma Putri ${ }^{*}$, Endang Darmawan², Dyah Aryani Perwitasari² \\ ${ }^{1}$ Mahasiswa Program Pascasarjana Farmasi, Fakultas Farmasi, Universitas Ahmad Dahlan, Jl. Prof. Soepomo, \\ SH., Yogyakarta, Indonesia \\ ${ }^{2}$ Fakultas Farmasi, Universitas Ahmad Dahlan, Jl. Prof. Soepomo, SH., Yogyakarta, Indonesia \\ *E-mail: ernikusuma@gmail.com
}

Received: 27 September 2019; Accepted: 26 Desember 2019; Published: 31 Desember 2019

\begin{abstract}
Abstrak
Diabetes melitus tipe 2 merupakan penyakit kronis yang membutuhkan terapi seumur hidup dan biaya pelayanan besar. Tujuan penelitian ini yaitu mengetahui besar biaya terapi berdasarkan jenis obat, perbedaan biaya riil dengan tarif INA-CBG's pasien diabetes melitus tipe 2 dan komplikasinya rawat jalan peserta Jaminan Kesehatan Nasional di Rumah Sakit Condong Catur Yogyakarta. Metode penelitian yang digunakan merupakan observasional. Analisis data dengan menghitung rata-rata biaya medis langsung (obat dan non obat). Analisis statistik uji independent T-test, Anova, Kruskal Wallis untuk mengetahui kesesuaian biaya riil dengan tarif INA-CBG's. Hasil penelitian menunjukkan rata-rata biaya terapi kelompok mikrovaskular Rp 3.164.732 per bulan, makrovaskular Rp 9.984.566 per bulan, mikrovaskular dan makrovaskular Rp 11.534.060 per bulan. Besar biaya terapi berdasarkan jenis obat (oral, insulin, oral dan insulin) kelompok

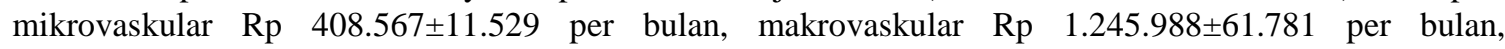
mikrovaskular dan makrovaskular Rp 2.059.959 168.856 per bulan. Perbedaan selisih antara total biaya riil dan total tarif INA-CBG's, kelompok mikrovaskular Rp -38.741,14 per pasien, makrovaskular Rp 10.914,03 per pasien, sedangkan mikrovaskular dan makrovaskular Rp 3.272,90 per pasien ini menunjukkan bahwa ketiga kelompok komplikasi tidak adanya perbedaan signifikan $p=0,207$ ( $p>0,005)$. Ada perbedaan besar biaya terapi pasien diabetes melitus tipe 2 dan komplikasinya yang dipengaruhi jenis komplikasi yang berbeda, jumlah episode kunjungan pasien, penggunaan obat tiap kelompok komplikasi berbeda. Terdapat selisih antara biaya riil dengan tarif INA-CBG's pada masing-masing kelompok komplikasi dimana biaya riil lebih tinggi dibandingkan tarif INA-CBG's.
\end{abstract}

Kata Kunci: Biaya Medis Langsung, Diabetes Melitus Tipe 2, Rawat Jalan

\begin{abstract}
DM-2 is a chronic disease that requires lifelong therapy and high service costs. This study is to determine the cost of therapy based on the type of drug, the difference in real costs with INA-CBG rates of outpatient DM-2 and complication therapy for JKN participants in Condong Catur Hospital Yogyakarta. The research used observational design. Data analysis by calculating the average direct medical costs. Statistical analysis of independent T-test, Anova, Kruskal Wallis to determine the suitability of real costs with INA-CBG rates. The results showed the average cost of microvascular group was $R p$ 3,164,732, macrovascular $R p$ 9,984,566, microvascular and macrovascular Rp 11,534,060 per month. The cost of therapy is based on the type of microvascular group drug (oral, insulin, oral and insulin) Rp. 408,567 \pm 11.529 , macrovascular Rp. $1.245 .988 \pm 61.781$, microvascular and macrovascular $R p$. 2.059.959 \pm 168.856 per month. The difference between the total real costs and the total INA-CBG's rates, the microvascular $R p$. -38,741.14, the macrovascular $R p-10,914.03$, while the microvascular and macrovascular group Rp 3,272.90 per patient. This shows that of the three groups of complications there was no significant difference $p=0.207(p>0.005)$. There is a large difference in the cost of therapy for patients with DM-2 and complication that is influenced by different types of complications, the number of episodes of patient visits, the use of drugs for each group of different complications. There is a difference between the real costs and the INA-CBG rates in each complication group where the real costs are higher than the INA-CBG.
\end{abstract}




\section{PENDAHULUAN}

Diabetes melitus (DM) adalah kelompok penyakit metabolik dengan karakteristik berupa hiperglikemia yang terjadi karena adanyan kelainan sekresi insulin, kerja insulin atau keduanya (ADA, 2017). Indonesia mengalami transisi epidemiologi penyakit dan kematian yang awalnya didominasi oleh penyakit menular kemudian menjadi penyakit tidak menular (Kemenkes RI, 2014). Penyakit diabetes melitus ini tidak dapat disembuhkan tetapi dapat dikontrol sehingga memerlukan terapi dalam jangka waktu yang panjang dan seumur hidup. Strategi terapi diabetes melitus tipe 2 berupa terapi non farmakologi dan terapi farmakologi. Terapi non farmakologi mencakup perubahan pola hidup sehat sedangkan terapi farmakologi terdiri atas obat antidiabetik oral dan insulin (ADA, 2017). Tujuan dari tatalaksana terapi DM tipe 2 adalah menghilangkan keluhan, memperbaiki dan meningkatkan kualitas hidup serta mengurangi risiko terjadinya komplikasi (PERKENI, 2015).

Tingginya jumlah penderita diabetes melitus karena adanya faktor kerentanan genetik dan gaya hidup yang tidak sehat. Faktor gaya hidup yang tidak sehat yang diperkirakan dapat meningkatkan resiko terjadinya diabetes melitus adalah tubuh kurang gerak atau olahraga, merokok, konsumsi alkohol, obstructive sleep apnea (OSA) dan obesitas (Wu et al., 2014).

Diabetes melitus diklasifikasikan berdasarkan penyebab dan proses terjadinya penyakit yang terdiri atas diabetes tipe 1, diabetes tipe 2 , gestasional diabetes mellitus (GDM), dan diabetes tipe lain (ADA, 2017). Diabetes tipe 2 dapat menyebabkan komplikasi yang mengancam jiwa. Komplikasi diabetes melitus bisa dibagi menjadi 2 kategori yaitu makrovaskular dan mikrovaskular. Makrovaskular termasuk kardiovaskular, cerebrovaskular, obstruksi arteri perifer, sedangkan mikrovaskular termasuk retinopati, nepropati, dan neuropati (Kim et al., 2012).

Pada tahun 2017 Indonesia menempati posisi ke-6 dalam jumlah penderita diabetes melitus tertinggi di dunia setelah Mexico, Brazil, dan Amerika Serikat. Jumlah penderita diabetes melitus di Indonesia mencapai 10,3 juta orang dan diperkirakan akan meningkat menjadi 16,7 juta orang di tahun 2045 (IDF, 2017). Mayoritas penderita DM adalah DM tipe 2 (90-95\%) dibandingkan dengan DM tipe 1 (5-10\%) (IDF, 2015). Diabetes melitus menempati urutan ke-4 dalam sepuluh besar penyakit tidak menular yang ada di Yogyakarta pada tahun 2017 dengan jumlah 8.321 kasus di puskesmas dan 11.254 kasus di rumah sakit (Dinkes Yogyakarta, 2017).

Biaya adalah salah satu faktor penting yang perlu diperhatikan dalam pelayanan kesehatan. Analisis biaya dipergunakan untuk mengetahui rata-rata biaya medik langsung (direct medical cost) (Zhuo et al., 2013). Biaya medis langsung adalah input yang digunakan secara langsung untuk memberikan terapi. Biaya medis langsung ditanggung oleh penderita, keluarga maupun negara. Komponen biaya medis langsung yaitu biaya obat, diagnosa, periksa dan konsultasi dokter (Andayani, 2013). Pada penelitian sebelumnya, Malhan et.al., (2014) tentang perkiraan biaya medik langsung yang dikeluarkan pasien diabetes melitus tipe 2 di Turki yaitu biaya yang dikeluarkan akibat komplikasi makrovaskular yaitu kardiovaskular menduduki peringkat terbesar (24,3\%-32,6\%), komplikasi nefropati (25\%$28,3 \%)$, biaya antidiabetik $(10,9 \%-12,3 \%)$ dan biaya pemeriksaan dokter (4,4\%-5\%).

Penelitian Baroroh dkk., (2016) tentang terapi diabetes melitus tipe 2 di RS. PKU Muhammadyah Bantul Yogyakarta pada pasien DM tipe 2 rawat jalan dan rawat inap hasil penelitian total rata-rata biaya terapi pasien DM tipe 2 rawat jalan tanpa 
komplikasi berkisar antara Rp.247.309 sampai Rp.686.753 per bulan. Total rata-rata biaya terapi pasien DM tipe 2 rawat jalan dengan komplikasi berkisar antara Rp.128.143 sampaiRp.1.174.342 per bulan,dipengaruhi oleh jenis terapi antidiabetik, biaya obat antidiabetik, dan biaya obat komplikasi.

Penelitian Mursalin dan Soewondo tahun 2016 di RSUD dr. Abdul Aziz Singkawang dengan dengan jumlah pasien 200 orang. Metode penelitian kuantitatif analitik, dengan menggunakan data sekunder yang dikumpulkan secara retrospektif, dengan uji normalitas data dan uji one sample Kolmogorov-Smirnov Tes. Hasil penelitian rata-rata biaya medis langsung untuk setiap penderita diabetes melitus tipe 2 rawat jalan dalam setahun sebesar Rp. 2.406.325. Komponen biaya terbesar adalah obat sebesar $(75,65 \%)$ yang terdiri atas obat antidiabetik $(47,32 \%)$ dan obat non antidiabetik $(28,34 \%)$. Biaya non obat-obatan $(24,35 \%)$ terdiri atas biaya pemeriksaan laboratorium $(9,14 \%)$, biaya poliklinik penyakit dalam $(7,83 \%)$, biaya pelayanan apotek $(3,76 \%)$, biaya pendaftaran $(1,98 \%)$, total biaya pemeriksaan EKG, poliklinik bedah, poliklinik mata, poliklinik syaraf, dan poliklinik fisioterapi sebesar (1\%). Dengan adanya komorbid atau penyakit penyerta akan menyebabkan bertambahnya biaya akibat penggunaan obat untuk mengatasinya. Penyakit penyerta juga dapat memperburuk kondisi pasien sehingga biaya terapi akan meningkat (Baroroh et al., 2016).Dalam menjawab berbagai tantangan tersebut diperlukan pemikiran-pemikiran khusus dalam peningkatan efisiensi atau penggunaan dana secara lebih rasional.

Diabetes melitus merupakan penyakit kronis yang diakui pemerintah Indonesia sebagai masalah kesehatan masyarakat, dengan konsekuensi tidak hanya pada efek yang tidak dikehendaki, tetapi juga menjadi beban ekonomi pada sistem pelayanan kesehatan. Epidemik diabetes telah berkembang di seluruh dunia dan berpotensi mengakibatkan kerugian pada sistem kesehatan dan ekonomi di negara-negara berkembang, baik dari segi biaya langsung perawatan kesehatan maupun kehilangan produktivitas diri (Soewondo et al., 2013).

Besarnya pembiayaan kesehatan dan prevalensi penyakit diabetes melitus berdampak negatif pada ekonomi dan produktivitas suatu bangsa. Pemerintah menyediakan sarana pelayanan kesehatan, asuransi dan mengeluarkan biaya yang besar untuk penanggulangan penyakit diabetes melitus. Pemerintah Indonesia melalui Kementerian Kesehatan Republik Indonesia mengembangkan beberapa program untuk penanggulangan penyakit diabetes melitus, salah satunya adalah Sistem Jaminan Sosial Nasional (SJSN) (Kemenkes RI., 2014).

Sistem Jaminan Sosial Nasional merupakan program negara yang bertujuan memberikan kepastian perlindungan dan kesejahteraan sosial bagi seluruh rakyat agar dapat memenuhi kebutuhan dasar hidupnya yang layak, maka pemerintah bertanggung jawab atas pelaksanaan jaminan kesehatan masyarakat melalui program JKN (Kemenkes RI., 2014). JKN dijalankan oleh Badan Penyelenggara Jaminan Sosial (BPJS). Dalam sistem JKN, BPJS Kesehatan akan membayar dengan sistem paket INA-CBGs (Indonesia Case Base Group) untuk Fasilitas Kesehatan Rujukan Tingkat Lanjutan (FKRTL) (Kemenkes RI, 2013). INA-CBGs adalah sistem paket pembayaran berdasarkan penyakit yanng diderita pasien. Tarif INACBGs merupakan rata-rata biaya yang dihabiskan oleh suatu kelompok diagnosis (BPJS Kesehatan, 2014). Dalam penerapannya sering kali ditemukan ketidaksesuaian antara biaya riil yang digunakan untuk terapi dengan tarif INACBGs.

Estimasi biaya penyakit Cost of Illnes (COI) merupakan elemen penting dalam proses pengambilan keputusan penyakit kronis seperti diabetes melitus, karena dapat mengevaluasi besarnya biaya dari suatu penyakit dan dapat menggambarkan penyakit yang membutuhkan peningkatan alokasi 
sumber daya untuk pencegahan penyakit atau terapi (Andayani., 2013). Oleh sebab itu penelitian mengenai biaya terapi diabetes melitus tipe 2 sangat diperlukan dalam membuat suatu kebijakan dalam era JKN ini.

\section{METODE PENELITIAN \\ Desain dan Jenis Penelitian}

Penelitian ini merupakan penelitian observasional. Analisis yang digunakan merupakan analisis biaya dihitung dari besar biaya dalam unit moneter (rupiah). Pengambilan data dilakukan melalui penelusuran data pasien BPJS di bagian rekam medik, data biaya pengobatan pasien diabetes melitus tipe 2 di bagian instalasi farmasi dan data klaim paket INA-CBG's diagnosa diabetes melitus tipe 2 di bagian keuangan. Penelitian ini merupakan jenis cost of illnes yang bertujuan untuk mengetahui total biaya terapi yang ditimbulkan dari penyakit diabetes melitus tipe 2 . Perspektif penyedia layanan kesehatan (peyer) yaitu Badan Penyelenggara Jaminan Sosial (BPJS), yang dilakukan pada pasien diabetes melitus tipe 2 rawat jalan di RS Condong Catur Yogyakarta.

\section{Materi Penelitian}

\section{Populasi}

Populasi target dalam penelitian ini adalah semua data pasien diabetes melitus tipe 2 rawat jalan RS Condong Catur Yogyakarta bulan Agustus sampai Oktober tahun 2018.

\section{Populasi terjangkau}

Populasi terjangkau dalam penelitian ini adalah semua data pasien diabetes melitus tipe 2 rawat jalan RS Condong Catur Yogyakarta pada tahun 2018 dalam kriteria inklusi :

a) Pasien berusia $\geq 18$ tahun

b) Pasien diabetes melitus yang menggunakan obat diabetes melitus 3 bulan sebelum penelitian dan kontrol rutin di bulan Agustus sampai Oktober tahun 2018.

c) Pasien peserta Badan Penyelenggara Jaminan Sosial (BPJS) d) Pasien dengan ICD 10 (penyakit diabetes melitus) E.11 (diabetes melitus tipe 2) dan mempunyai komplikasi

Kriteria eklusinya yaitu :

a) Pasien yang meninggal selama perawatan

b) Data pasien yang kurang lengkap baik data rekam medis maupun perincian biaya medis langsung dari bagian keuangan, hilang, atau tidak terbaca.

c) Pasien dengan DM tipe 1

d) Pasien wanita dengan DM gestasional

\section{Alat dan Bahan Penelitian}

\section{Alat Penelitian}

Alat yang digunakan dalam penelitian berupa alat tulis dan lembar pengumpul data yang berisi jenis kelamin, usia, komplikasi, penyakit penyerta dan terapi yang diberikan. Pengolahan data dilakukan dengan SPSS dan Microsoft excel

\section{Bahan Penelitian}

Bahan penelitian diambil berdasarkan data pasien BPJS di bagian rekam medik, rincian biaya terapi per bulan selama tiga bulan terakhir di bagian farmasi, dan data klaim tarif INA-CBGs di bagian keuangan.

\section{Prosedur Penelitian}

\section{Tahap Persiapan}

Tahap awal dalam penelitian ini yaitu mencari studi pustaka untuk menyusun usulan proposal tesis yang akan diajukan kepada Program Pasca Sarjana Universitas Ahmad Dahlan Yogyakarta, dilanjutkan dengan seminar proposal tesis dan perbaikan sesuai hasil seminar proposal tesis, kemudian melakukan proses perijinan penelitian di RS Condong Catur Yogyakarta.

\section{Tahap Pelaksanaan Penelitian}

Pelaksanaan penelitian dilakukan dalam bentuk beberapa kegiatan yaitu :

a. Pengumpulan data dalam penelitian ini dilakukan secara langsung dengan mengamati sumber data di bagian Sistem Informasi Rumah Sakit (SIRS) rumah sakit, rekam medik, instalasi farmasi dan bagian pengelolaan keuangan. Data rincian medik langsung dan data klaim INA-CBG's pasien diabetes melitus rawat jalan periode Agustus sampai Oktober 2018 dikumpulkan 
menggunakan lembar pengumpulan data yang telah dipersiapkan.

b. Rincian biaya terapi pasien diabetes melitus tipe 2 yang dilakukan di rawat jalan RS. Condong Catur Yogyakarta tahun 2018 diperoleh data dari instalasi farmasi yang meliputi rincian biaya obat antidiabtes melitus, biaya obat non antidiabtes melitus, biaya pemeriksaan dan konsultasi dokter, biaya laboratorium dan biaya tindakan medik yang diperlukan di bagian keuangan.

\section{Tahap Penyelesaian}

a) Melakukan analisis data dan menyususn pembahasan hasil penelitian berdasarkan analisis data yang telah diperoleh dan dilanjutkan penyusunan laporan penelitian dalam bentuk tertulis.

b) Tahap selanjutnya dilakukan ujian tesis dan dilakukan perbaikan sesuai hasil ujian tesis.

c) Penyerahan hasil laporan tesis penelitian yang telah diperbaiki kepada Program Pasca Sarjana Universitas Ahmad Dahlan Yogyakarta.

\section{HASIL DAN PEMBAHASAN \\ Karakteristik Subyek Penelitian}

Berdasarkan data penelitian diperoleh total pasien rawat jalan dengan diagnosa diabetes melitus tipe 2 yang rutin berobat selama 3 bulan sebelum penelitian dan kontrol rutin di bulan Aguatus sampai Oktobe 2018 di poli penyakit dalam RS Condong Catur Yogyakarta sebanyak 196 pasien yang masuk dalam kriteria inklusi dan eksklusi, dilakukan eksklusi pada pasien diabetes melitus tipe 2 sebanyak 73 pasien dengan diagnosa diabetes melitus tipe 2 tanpa komplikasi, sehingga diperoleh subyek penelitian sebanyak 123 pasien dengan diagnosa diabetes melitus tipe 2 dengan komplikasi yang masuk dalam kriteria inklusi penelitin.

\section{Gambaran Karakteristik Demografi}

Berdasarkan hasil penelitian menunjukkan bahwa jumlah pasien diabetes melitus tipe 2 rawat jalan dengan komplikasi di RS Condong Catur Yogyakarta selama periode Agustus-Oktober 2018 lebih banyak terdapat pada perempuan dengan jumlah 79 $(64,2 \%)$ daripada laki-laki 44 (35,8\%). Hasil penelitian ini tidak jauh berbeda dari penelitian Watetu et al., (2019) di Rumah Sakit Kabupaten Kiambu, Kenya pada pasien Diabetes Tipe 2 menunjukkan bahwa perempuan sebanyak $91(59,5 \%)$ laki-laki $62(40,5 \%)$ sedangkan pada penelitian Yosmar et al., (2018) di masyarakat Kota Padang menunjukkan bahwa perempuan sebanyak 186( 53,4\%) dan laki-laki 162 (46,6\%).

Pada penelitian ini kategori usia di bagi menjadi 3 kelompok berdasarkan Kementerian Kesehatan tahun 2018 yaitu 1844 tahun, 45-64 tahun, dan $\geq 65$ tahun pada masing-masing kelompok mikrovaskular, makrovaskular, serta mikrovaskular dan makrovaskular.

Pada penelitian ini diperoleh hasil bahwa pasien diabetes melitus tipe 2 rawat jalan terbanyak kelompok makrovaskular pada kategori usia 45-64 tahun dengan jumlah 36 pasien $(29,3 \%)$. Hal tersebut sama dengan penelitian Yosmar et al., (2018) bahwa penderita diabetes meltus tipe 2 umumnya berumur 45-74 tahun ini dikarenakan semakin bertambahnya usia, kerja dari organ tubuh semakin berkurang sehingga dapat meningkat risiko terkena penyakit. Sesuai dengan data IDF (2013) menyatakan bahwa sebagian besar penderita diabetes berada pada rentang umur 40-59 tahun dan $80 \%$ pasien diabetes melitus pada kelompok umur ini berada pada negara berkembang seperti Indonesia, dan tidak menutup kemungkinan orang yang berumur $<45$ tahun bisa terkena penyakit diabetes melitus.

Lama menderita diabetes melitus tipe 2 ini menunjukkan bahwa berapa lama pasien menderita diabetes melitus tipe 2 dimulai dari penegakkan diagnosa sampai penelitian ini dilaksanakan. Keparahan dan lamanya pasien menderita diabetes melitus tipe 2 berhubungan dengan berkembangnya risiko terjadinya penyakit komplikasi. Penyakit komplikasi diabetes melitus dapat 
membahayakan nyawa pasien, ini disebabkan karena penumpukan glukosa di dalam darah yang tidak dapat diserap oleh sel tubuh secara baik sehingga dapat menimbulkan berbagai gangguan di organ tubuh karena glukosa merupakan sumber energi utama bagi sel tubuh manusia.

Hasil penelitian ini diperoleh lamanya pasien menderita diabetes melitus tipe 2 dibagi menjadi 2 kelompok yaitu $<1$ tahun 30 pasien $(24,4 \%)$ dan $1-5$ tahun 93 pasien $(75,6 \%)$. Pasien terbanyak terdapat pada komplikasi makrovaskular dengan lama menderita $<1$ tahun yaitu 11 pasien $(36,7 \%)$, 1-5 tahun yaitu 46 pasien $(49,5 \%)$, sejalan dengan penelitian Jakson et al (2014) lamanya pasien menderita diabetes melitus < 1 tahun $(10,9 \%), 1-5$ tahun $(34,7 \%)$ hal ini terjadi karena kurangnya kesadaran pasien dalam mengontrol kadar gula darah sehingga akan berakibat pada penyakit komplikasi dan berpengaruh pada kualitas hidup pasien serta dapat mengakibatkan biaya terapi penyakit diabetes melitus semakin meningkat.

Hasil uji Chi Square data deskriptif jenis kelamin, usia, dan lama menderita pada pasien dengan penyakit komplikasi mikrovaskular, makrovaskular, mikrovaskular dan makrovaskulr diabetes melitus Tipe 2 yaitu nilai $p>0,05$ yang berarti tidak ada perbedaan signifikan antara jenis kelamin dan usia pada penyakit komplikasi, sedangkan pada $\mathrm{p}<0,05$ berbeda signifikansinya yang artinya ada perbedaan signifikan antara lama menderita dengan penyakit komplikasi.

\section{Diagnosa Pasien DM Tipe 2}

Diagnosa pasien diabetes melitus tipe 2 berdasarkan hasil data rekam medis pasien diabetes melitus tipe 2 dan Sistem Informasi Rumah Sakit (SIRS) dengan kode ICD 10 (Penyakit diabetes melitus) E11 (penyakit diabetes melitus tipe 2). Pengelompokan pasien dengan penyakit komplikasi diperoleh berdasarkan diagnosa komplikasi oleh dokter dan obat-obatan yang diberikan kepada pasien diabetes melitus tipe 2 . Jumlah pasien yang menderita komplikasi pada penelitian ini total sebanyak 123 pasien dengan komplikasi mikrovaskular sebanyak 17 pasien, makrovaskular 57 pasien, sedangkan microvaskular dan makrovaskular sebanyak 49 pasien.

Komplikasi pada penelitian ini merupakan komplikasi kronis yang di derita oleh pasien diabetes melitus tipe 2 terdiri atas mikrovaskular (neuropati, retinopati dan nefropati), makrovaskular (hipertensi, dislipidemia, hiperuricemia, asma, jantung) serta kombinasi kedua komplikasi tersebut (mikrovaskular dan makrovaskular). Menurut WHO (2016) setelah usia mencapai 30 tahun kadar glukosa darah akan naik 1-2 mg/dL per tahun (saat puasa) dan naik sebesar 5,6-13 $\mathrm{mg} / \mathrm{dL}$ per tahun (2 jam setelah makan), sehingga dengan tingginya kadar gula darah yang tinggi secara terus-menerus dapat mengakibatkan timbulnya komplikasi diabetes melitus. Komplikasi utama dari penyakit diabetes melitus yaitu komplikasi makrovaskular yang merupakan penyakit kardiovaskular sebesar $65 \%$ dari komplikasi diabetes melitus dan merupakan penyebab utama kematian pada pasien dengan diabetes melitus tipe 2 Barr dkk., (2007).

Penelitian ini menunjukkan jumlah pasien komplikasi pada masing-masing kelompok terbanyak yaitu komplikasi makrovaskular sebanyak 57 pasien $(46,34 \%)$ terutama pada penyakit hipertensi sebanyak 31 pasien $(25,20 \%)$, pada kelompok mikrovaskular dan makrovaskular sebanyak 49 pasien $(39,83 \%)$ yaitu pada penyakit neuropati dan hipertensi sebanyak 18 pasien $(14,63 \%)$ sedangkan pada kelompok mikrovaskular sebanyak 17 pasien $(13,82 \%)$ yaitu pasien pada penyakit neuropati sebanyak 14 pasien $(11,38 \%)$. Penelitian yang sama pada Soewondo P dkk., (2016) di RSUD Dr. Abdul Aziz Singkawang membuktikan bahwa komplikasi terbanyak pada penderita diabetes yaitu komplikasi makrovaskular $(45,5 \%)$, komplikasi mikrovaskular dan makrovaskular (26,0\%), komplikasi mikrovaskular (10,5\%), dan yang tidak mengalami komplikasi 
Tabel 1. Jumlah Kejadian dan Biaya Komplikasi Pada Pasien Diabetes Melitus Tipe 2 Rawat Jalan RS Condong Catur Yogyakarta ( $n=123$ pasien)

\begin{tabular}{|c|c|c|c|}
\hline Jenis Komplikasi & $\begin{array}{c}\text { Jumlah } \\
\text { pasien } \\
(\mathrm{n})\end{array}$ & $\begin{array}{c}\text { Presentase } \\
(\%)\end{array}$ & $\begin{array}{c}\text { Biaya rata-rata } \\
\text { per bulan }\end{array}$ \\
\hline \multicolumn{4}{|l|}{ Mikrovaskular: } \\
\hline Neuropati & 14 & 11,38 & Rp 192.913 \\
\hline Retinopati & 3 & 2,44 & Rp 149.419 \\
\hline Jumlah & 17 & 13,82 & Rp 342.332 \\
\hline \multicolumn{4}{|l|}{ Makrovaskular : } \\
\hline Hipertensi & 31 & 25,20 & Rp 567.516 \\
\hline Hipertensi+Dislipidemia & 17 & 13,82 & Rp 148.119 \\
\hline Hipertensi+Dislipidemia+Jantung & 3 & 2,44 & Rp 136.160 \\
\hline Hipertensi+Jantung & 4 & 3,25 & $\mathrm{Rp} \quad 41.262$ \\
\hline Jantung & 2 & 1,63 & Rp 179.522 \\
\hline Jumlah & 57 & 46,34 & Rp 1.072.579 \\
\hline \multicolumn{4}{|l|}{ Mikrovaskular dan makrovaskular : } \\
\hline Neuropati+Retinopati+Hipertensi+Jantung & 2 & 1,63 & Rp 263.451 \\
\hline Neuropati+Hipertensi & 18 & 14,63 & Rp 326.345 \\
\hline Neuropati+Dislipidemia & 4 & 3,25 & Rp 36.923 \\
\hline Neuropati+Hipertensi+Dislipidemia & 7 & 5,70 & Rp 108.266 \\
\hline Neuropati+Hipertensi+Jantung & 3 & 2,44 & Rp 122.846 \\
\hline Neuropati+Hipertensi+Dislipidemia+Jantung & 1 & 0,81 & Rp 61.040 \\
\hline Neuropati+Retinopati+Hiperurisemia & 1 & 0,81 & $\mathrm{Rp} \quad 38.276$ \\
\hline Neuropati+Hipertensi+Jantung & 1 & 0,81 & Rp 41.986 \\
\hline Neuropati+Retinopati+Dislipidemia & 1 & 0,81 & Rp 67.355 \\
\hline Neuropati+Retinopati+Jantung & 1 & 0,81 & $\mathrm{Rp} \quad 39.688$ \\
\hline Retinopati+Hipertensi+Dislipidemia & 3 & 2,44 & Rp 344.091 \\
\hline Retinopati+Hipertensi+Jantung & 2 & 1,63 & Rp 116.274 \\
\hline Nefropati+Jantung & 1 & 0,81 & Rp 120.277 \\
\hline Nefropati+Hipertensi & 4 & 3,25 & $\mathrm{Rp} 231.276$ \\
\hline Jumlah & 49 & 39,83 & Rp 1.918.101 \\
\hline
\end{tabular}

$(18,0 \%)$ sebagaimana ditunjukkan pada Tabel 1 .

\section{Gambaran Terapi Pada Pasien Diabetes Melitus Tipe 2}

Dalam mengelola diabetes melitus langkah pertama yang harus dilakukan adalah pengelolaan non farmakologi, berupa perencanaan makanana berserat tinggi, diet lemak, tidak merokok, tidak mengkonsumsi alkohol dan olah raga yang tertur, kemudian jika dengan langkah-langkah tersebut sasaran pengendalian diabetes melitus yang telah ditentukan belum tercapai, maka dilanjutkan dengan penggunaan obat atau pengelolaan farmakologi. Terapi farmakologi diperlukan untuk mencapai target glukosa darah.

Kadar glukosa darah pada pasien diabetes melitus harus tetap dijaga supaya risiko terjadinya komplikasi dapat dicegah. Penggunaan obat antidiabetes didasarkan pada berbagai pertimbangan sesuai kondisi dari masing-masing pasien. Obat antidiabetes terdiri dari oral, insulin, dan kombinasi keduanya (PERKENI, 2015). Pada penelitian ini golongan obat antidiabetes yang digunakan terdiri dari sulfonilurea (glimepiride, glikazide, glikuidone), biguanid (metformin), thiazolidinedion (pioglitazone), penghambat $\alpha$ glukosidase (acarbose), insulin yang terdiri dari novomix flexpen dan humalog Mix 25 (human premixed), novorapid (rapid-acting), lantus solostar (long-acting)).

Pada Tabel 2 kombinasi obat yang sering digunakan adalah glimepiride dan metformin yang merupakan golongan sulfonilurea dan 
biguanid sebanyak 15 pasien $(12,19 \%)$ pada kompliksi mikrovaskular dan makrovaskular, kelompok makrovaskular sebanyak 11 pasien $(8,94 \%)$ pada kombinasi glimepiride, metformin dan acarbose, kelompok mikrovaskular sebanyak 4 pasien $(3,25 \%)$ dengan menggunakan kombinasi obat glimepiride, metformin dan acarbose sedangkan pada pemakaian insulin pada kelompok makrovaskular 1 pasien $(0,81 \%)$ kombinasi insulin dengan antidiabetes oral ada 1 pasien $(0,81 \%)$, sedangkan pada kelompok mikrovaskular dan makrovaskular penggunaan insulin ada 4 pasien $(3,25 \%)$, kombinasi obat antidiabetes oral dan insulin 1 pasien $(1 \%)$.

Penelitian sebelumnya menunjukkan bahwa prevalensi penggunaan kombinasi antidiabetes glimepiride dan metformin di Mesir (8,3\%), Indonesia (9,1\%), Myanmar $10,5 \%$, Nepal $(5,6 \%)$, sedangkan pada kombinasi glimepiride,metformin dan acarbose di Kuwait (21\%), Uganda $(1,4 \%)$, ini membuktikan bahwa pemberian awal kombinasi obat antidiabetes dapat mengontrol kadar gula darah yang tinggi dan mengurangi terjadinya komplikasi mikrovaskular maupun makrovaskular.

Pada penelitian di Inggris membuktikan bahwa penggunaan kombinasi antidiabetes oral dengan insulin lebih efektif dan aman, tetapi tetap mempertimbangkan mekanisme kerja dari masing-masing obat tersebut, hal ini sama dengan penelitian Lingvay I et al., (2009) yang mengatakan bahwa pemakaian insulin lebih efektif dan tidak menyebabkan kenaikan berat badan atau hipoglikemia, pemakaian insulin lebih aman, dapat diterima dengan baik oleh pasien dan efektif untuk perawatan pasien diabetes tipe 2 yang baru didiagnosis.

\section{Analisa Biaya Terapi pada Pasien Diabetes Melitus Tipe 2}

Data biaya obat antidiabetes, non antidiabetes dan biaya medis langsung pasien antidiabetes melitus tipe 2 RS Condong Catur Yogyakarta didapatkan dari rincian biaya nama pasien, nomor rekam medis, nomor registrasi, tanggal kunjungan pasien. Rincian biaya medis langsung diperoleh di bagian keuangan dan biaya obat antidiabetes maupun non antidiabetes dadapatkan di bagian instalasi farmasi dalam Sistem Informasi Rumah Sakit (SIRS). Rincian biaya tersebut dikelompokkan menjadi biaya obat antidiabetes, obat non antidiabetes, biaya periksa dan konsultasi dokter, biaya tes laboratorium, dan biaya tindakan.

\section{Biaya Obat Antidiabetes}

Kelompok biaya obat di bagi menjadi 2 yaitu biaya obat antidiabetes dan biaya obat non antidiabetes (biaya komplikasi). Obat antidiabetes yang digunakan dalam terapi pasien diabetes melitus yaitu sulfonilurea, biguanid, thiazolidinedion, penghambat $\alpha$ glukosidase, serta insulin. Biaya obat non antidiabetes yaitu biaya yang dikeluarkan pasien untuk mengatasi penykit komplikasi mikrovaskular, makrovaskular, mikrovaskular dan makrovaskular. Biaya obat rata-rata pasien per bulan yaitu sebesar Rp 408.567 (mikrovaskular), Rp1.245.987 (makrovaskular), $\quad \mathrm{Rp} \quad 2.059 .959$ (mikrovaskular dan makrovaskular). Variasi implikasi, jenis antidiabetes dan dosis yang digunakan.

\section{Biaya Obat Komplikasi}

Biaya obat komplikasi yaitu biaya obat yang dikeluarkan pasien untuk mengatasi komplikasi dari penyakit yang dideritanya (Obat non antidiabetes melitus). Pada Tabel 1 membuktikan bahwa biaya kelompok komplikasi terbesar yaitu pada komplikasi mikrovaskular dan makrovaskular dengan total biaya rata-rata per bulan yaitu Rp 1.918.101, biaya komplikasi rata-rata yang paling besar pada kelompok ini yaitu pada komplikasi retinopati,hipertensi dan dislipidemia sebesar Rp 344.091 per bulan , yang kemudian diikuti komplikasi neuropati dan hipertensi sebesar Rp 326.345 per bulan. Pada kelompok makrovaskular biaya terbesar pada komplikasi hipertensi Rp 567.516 dan dilanjutkan kelompok komplikasi mikrovaskular sebessar Rp 192.913 pada komplikasi neuropati.biaya obat antidiabetes 
Tabel 2. Gambaran Jenis Obat dan Rata-rata Biaya Obat Antidiabetes Melitus yang Digunakan pada Pasien Diabetes Melitus Tipe 2 Rawat Jalan Berdasarkan Penyakit Komplikasi di RS Condong Catur Yogyakarta $(\mathbf{n}=123)$

\begin{tabular}{|c|c|c|c|}
\hline Jenis Terapi & $\begin{array}{c}\text { Jumlah } \\
\text { pasien } \\
\text { (n) }\end{array}$ & $\begin{array}{c}\text { Presentase } \\
(\%)\end{array}$ & $\begin{array}{c}\text { Biaya rata-rata } \\
\text { per bulan }\end{array}$ \\
\hline \multicolumn{4}{|l|}{ Mikrovaskular : } \\
\hline Glimepiride+Metformin+Pioglitazone+Acarbose & 2 & $1,63 \%$ & Rp 51.707 \\
\hline Glimepiride+Metformin & 3 & $2,44 \%$ & $\mathrm{Rp} \quad 12.483$ \\
\hline Glimepiride+Pioglitazone & 2 & $1,63 \%$ & Rp 61.369 \\
\hline Glimepiride+Metformin+Pioglitazone & 2 & $1,63 \%$ & Rp 55.541 \\
\hline Glimepiride+Metformin+Acarbose & 4 & $3,25 \%$ & Rp $\quad 59.829$ \\
\hline Glimepiride + Acarbose & 1 & $0,81 \%$ & $\mathrm{Rp} \quad 16.766$ \\
\hline Metformin & 2 & $1,63 \%$ & $\mathrm{Rp} \quad 5.024$ \\
\hline Metformin+Pioglitazone+Insulin & 1 & $0,81 \%$ & Rp 145.845 \\
\hline Jumlah & 17 & $13,83 \%$ & Rp 408.567 \\
\hline \multicolumn{4}{|l|}{ Makrovaskular: } \\
\hline Metformin & 8 & $6,50 \%$ & Rp 10.048 \\
\hline Metformin+Acarbose & 2 & $1,63 \%$ & $\operatorname{Rp} \quad 22.517$ \\
\hline Glimepiride & 3 & $2,44 \%$ & $\mathrm{Rp} \quad 6.921$ \\
\hline Glimepiride+Metformin & 10 & $8,13 \%$ & Rp 63.689 \\
\hline Glimepiride+Metformin+Acarbose & 11 & $8,94 \%$ & Rp 208.592 \\
\hline Glimepiride+Metformin+Acarbose+Insulin & 1 & $0,81 \%$ & Rp 118.843 \\
\hline Glimepiride+Metformin+Pioglitazone & 7 & $5,69 \%$ & Rp 168.577 \\
\hline Glimepiride+Metformin+Pioglitazone+Acarbose & 2 & $1,63 \%$ & Rp 87.318 \\
\hline Glimepiride+Metformin+Pioglitazone+Insulin & 1 & $0,81 \%$ & Rp 188.543 \\
\hline Glimepiride+Pioglitazone+Acarbose & 1 & $0,81 \%$ & $\mathrm{Rp} \quad 34.000$ \\
\hline Glimepiride+Pioglitazone & 5 & $4,07 \%$ & Rp 136.673 \\
\hline Glikazide+Metformin & 1 & $0,81 \%$ & $\mathrm{Rp} \quad 4.922$ \\
\hline Glikazide+Metformin+Acarbose & 1 & $0,81 \%$ & Rp 8.849 \\
\hline Glikuidone & 1 & $0,81 \%$ & Rp 12.473 \\
\hline Insulin & 1 & $0,81 \%$ & Rp 128.722 \\
\hline Pioglitazone+Acarbose & 1 & $0,81 \%$ & Rp $\quad 29.215$ \\
\hline Pioglitazone & 1 & $0,81 \%$ & Rp 16.077 \\
\hline Jumlah & 57 & $46,32 \%$ & Rp 1.245.987 \\
\hline \multicolumn{4}{|l|}{ Mikrovaskular dan makrovaskular: } \\
\hline Pioglitazone+Insulin & 1 & $0,81 \%$ & Rp 151.154 \\
\hline Insulin & 4 & $3,25 \%$ & Rp 399.040 \\
\hline Glimepiride+Metformin+Insulin & 1 & $0,81 \%$ & Rp 391.383 \\
\hline Glimepiride+Metformin+Acarbose & 9 & $7,32 \%$ & Rp 135.120 \\
\hline Glimepiride+Metformin & 15 & $12,19 \%$ & $\mathrm{Rp} \quad 92.248$ \\
\hline Glimepiride & 3 & $2,44 \%$ & Rp 10.620 \\
\hline Glimepiride+Pioglitazone & 3 & $2,44 \%$ & Rp 64.954 \\
\hline Glimepiride+Metformin+Pioglitazone & 3 & $2,44 \%$ & Rp $\quad 60.770$ \\
\hline Glimepiride+Metformin+Pioglitazone+Acarbose & 3 & $2,44 \%$ & Rp 149.846 \\
\hline Metformin+Insulin & 2 & $1,63 \%$ & Rp 456.775 \\
\hline Metformin+Acarbose & 1 & $0,81 \%$ & $\operatorname{Rp} \quad 7.577$ \\
\hline Metformin+Pioglitazone+Acarbose & 1 & $0,81 \%$ & Rp 36.197 \\
\hline Glikuidone & 1 & $0,81 \%$ & $\mathrm{Rp} \quad 9.354$ \\
\hline Glikuidone+Pioglitazone & 1 & $0,81 \%$ & $\mathrm{Rp} \quad 47.086$ \\
\hline Glikazide+Metformin + Acarbose & 1 & $0,81 \%$ & Rp 19.883 \\
\hline Jumlah & 49 & $39,81 \%$ & Rp 2.059.959 \\
\hline
\end{tabular}

setiap pasien berbeda-beda karena disebabkan oleh kondisi penyakit
Pada penelitian Acharya et al., (2016) membuktikan bahwa biaya paling tinggi pada pasien diabetes yaitu biaya untuk komplikasi 
mikrovaskular dan makrovaskular yaitu 1,6 kali lebih tinggi dibandingkan biaya pasien tanpa komplikasi. Di India Utara biaya antidiabetes yang dikeluarkan oleh pasien dengan komplikasi sebesar 1448.51 rupee per bulan, sehingga biaya medis langsung yang dikeluarkan pasien untuk obat sebesar $(71,25 \%)$, biaya medis tidak langsung $(28,75 \%)$ dan biaya pelayanan kesehatan $(2,83 \%)$.

Pada penelitian sebelumnya menunjukkan bahwa total biaya pasien pasien diabetes rawat jalan sebesar 2.108 dolar Amerika per pasien dimana biaya medis langsung yang dikeluarkan pasien sebesar 1.335 dolar Amerika per pasien $(63,3 \%)$, sedangkan biaya medis tidak langsung sebesar 773 dolar Amerika per pasien (36,7\%). Pasien dengan komplikasi mikrovaskuler dan makrovaskular memiliki biaya yang lebih tinggi sebesar 3199 dolar Amerika per pasien dibandingkan pasien dengan komplikasi mikrovaskuler 2062 dolar Amerika per pasien atau makrovaskular 2.517 dolar Amerika per pasien.

Biaya Non Obat

Biaya non obat pada penelitian ini meliputi biaya periksa dan konsultasi dokter, biaya tes laboratorium, Biaya tindakan medis. Total biaya non obat per bulan diperoleh dari jumlah biaya periksa dan konsultasi dokter, biaya tes laboratorium, biaya tindakan medis yang diperoleh selama penelitian kemudian dibagi lamanya penelitian (3 bulan). Komponen biaya non obat pada setiap rumah sakit berbeda-beda, hal ini dipengaruhi oleh tipe rumah sakit, dokter yang menangani terapi (dokter umum, dokter spesialis, dokter sub spesialis), ada atau tidaknya tindakan medis yang perlu dilakukan, dan periode kunjungan pasien untuk berobat.

Biaya Riil/Medis Langsung

Biaya medis langsung pada penelitian ini terdiri dari biaya obat antidiabetes, biaya obat non antidiabetes, sedangkan biaya non obat terdiri dari biaya periksa dan konsultasi dokter, biaya tes laboratorium, biaya tindakan medis. Rata-rata biaya medis langsung per pasien setiap bulannya sebesar $\quad \mathrm{Rp}$ 3.164.732 per bulan (mikrovaskular), $\mathrm{Rp}$ 9.984.566 per bulan (makrovaskular), $\mathrm{Rp}$ 11.534.060 per bulan (mikrovaskular dan makrovaskular).

Untuk mengetahui rata-rata biaya obat antara penggunaan obat antidiabetes oral, insulin, oral dan insulin maka perlu dihitung setiap kelompok komplikasi, baik komplikasi mikrovaskular, makrovaskular, mikrovaskular dan makrovaskular.

\section{Komplikasi Mikrovaskular}

Pada kelompok mikrovaskular biaya rata-rata obat oral sebesar $\mathrm{Rp} 262.721$ dengan rentang biaya sekitar \pm Rp 11.529 per pasien dalam satu bulan. Rata-rata biaya obat antidiabetes dihitung berdasarkan jenis obat antidiabetes yang digunakan oleh pasien selama terapi, pada kelompok mikrovaskular biaya obat yang paling besar yaitu penggunaan obat oral.

Penelitian Kim H et al., (2012) di Korea yang membuktikan bahwa dari 1.883 pasien pada komplikasi mikrovaskular selain diet dan olahraga $(43,2 \%)$ penggunaan obat antidiabetes yang terbanyak yaitu obat antidiabetes oral $(46,2 \%)$, insulin $(5,5 \%)$, oral dan insulin $(5,2 \%)$ dengan total biaya komplikasi mikrovaskular sebesar 997,7 Won Korea (KRW).

\section{Makrovaskular}

Biaya rata-rata obat antidiabetes oral pada kelompok makrovaskular Rp $809.877 \pm$ Rp 12.496 (54 pasien), insulin Rp 128.723 (1 pasien), kemudian kombinasi oral dan insulin Rp $999.313 \pm \operatorname{Rp} 152.776$ (2 pasien), pada penelitian Dimitrova M et al., (2015) di rumah sakit Bulgaria membuktikan bahwa biaya terapi obat pada penyakit komplikasi makrovaskular sebesar EUR 213.87 (162.24) komplikasi mikrovaskular EUR 171.26 (146.09) sehingga biaya obat pada komplikasi makrovaskular lebih besar dari terapi obat pada kelompok mikrovaskular

Penelitian Kim H et al., (2012) di Korea menunjukkan bahwa pada kelompok komplikasi makrovaskular makrovaskular prevalensi penggunaan obat antidiabetes oral 
sebesar $20(39,2 \%)$, obat insulin $3(5,9 \%)$, serta pada kombinasi dari penggunaan oral dan insulin sebesar $2(3,9 \%)$. Total biaya penggunaan obat pada kelompok mikrovaskular dan makrovaskular sebesar 1.300,6 Won Kore (KRW)

\section{Mikrovaskular dan Makrovaskular}

Kelompok komplikasi mikrovaskular dan makrovaskular menunjukkan hasil bahwa penggunaan obat oral sebesar Rp $661.606 \pm$ Rp 14.741 (41 pasien), insulin Rp $399.040 \pm$ $\mathrm{Rp} 1.339$ (4 pasien), kemudian oral dan insulin sebesar $\mathrm{Rp} 999.313 \pm \mathrm{Rp} 152.776$. Penelitian Domeikiene A et al., (2015) di Lithuania menunjukkan bahwa pada kelompok mikrovaskular dan makrovaskular biaya obat antidiabetes oral sebesar EUR 74.73 (95\% CI, 65.07-84.39), insulin EUR 408.75 (95\% CI, 359.76-457.75), kemudian oral dan insulin sebesar EUR 508.94 (95\% CI, 425.81-592.07) dengan uji Kruskal Wallis didapatkan nilai $\mathrm{p}<0,001$.

Penelitian Kim H et al., (2012) di Korea menunjukkan bahwa pada kelompok komplikasi mikrovaskular dan makrovaskular prevalensi penggunaan obat antidiabetes oral sebesar $138(50,6 \%)$, obat insulin $22(8,1 \%)$, serta pada kombinasi dari penggunaan oral dan insulin sebesar $20(7,3 \%)$. Total biaya penggunaan obat pada kelompok mikrovaskular dan makrovaskular sebesar 1.384,5 Won Kore (KRW) dengan nilai $\mathrm{p}<$ 0.001 yang artinya berbeda signifikan.

\section{KESIMPULAN}

Berdasarkan hasil penelitian yang tentang cost of Ilness diabetes melitus tipe 2 rawat jalan peserta Jaminan Kesehatan Nasional (JKN) di Rumah Sakit Condong Catur Yogyakarta pada periode AgustusOktober 2018 dapat disimpulkan bahwa:

1. Besar biaya terapi pasien diabetes melitus tipe 2 rawat jalan pada komplikasi kelompok mikrovaskular Rp 3.164 .732 per bulan, kelompok makrovaskular $\mathrm{Rp}$ 9.984.566 per bulan, kelompok mikrovaskular dan makrovaskular $\mathrm{Rp}$ 11.534.060 per bulan

2. Besar biaya terapi pasien diabetes melitus tipe 2 rawat jalan berdasarkan jenis obat pada komplikasi kelompok mikrovaskular Rp 408.567 per bulan, kelompok makrovaskular Rp 1.245.987 per bulan, kelompok mikrovaskular dan makrovaskular Rp 2.059.959 per bulan.

3. Perbedaan selisih antara total biaya riil dan total tarif INA-CBG's, kelompok mikrovaskular $\mathrm{Rp}-38.741,14$ per pasien, kelompok makrovaskular Rp -10.914,03 per pasien, sedangkan pada kelompok mikrovaskular dan makrovaskular Rp $3.272,90$ per pasien. Didapatkan nilai signifikansi $\mathrm{p}=0,207 \quad(\mathrm{p}>0,05) \quad$ artinya menunjukkan tidak adanya perbedaan yang bermakna antara total biaya riil tiap kelompok komplikasi.

\section{Daftar Pustaka}

Acharya, L.D., Rau, N.R., Udupa, N., Rajan, M.S., Vijayanarayana, K., 2016. Assessment of cost of illness for diabetic patients in South Indian tertiary care hospital. Journal of Pharmacy \& Bioallied Sciences. 8 (4): 314-320

American Diabetes Association, 2017. Standards of Medical Care in Diabetes, Diabetes Care Journal, 60-80.

Andayani, T.M., 2013. Farmakoekonomi Prinsip Dan Metodologi. Bursa Ilmu, Yogyakarta

Baroroh, F., Solikah, W.Y., Urfiyya, Q. A., 2016, Analisis BiayaTerapi Diabetes Melitus Tipe 2 di Rumah Sakit PKU Muhammadyah Bantul Yogyakarta, Jurnal Farmasi Sains dan 
Praktis, 1 (2), 11-22.

Barr, E.L.M., Zimmet, P.Z., Welborn,T.A, Jolley., D, Magliano, D.J, 2014. Risk of Cardiovascular and All-Cause Mortality in Individuals With Diabetes Mellitus, Impaired Fasting Glucose, and Impaired Glucose Tolerance: The Australian Diabetes, Obesity, and Lifestyle Study (AusDiab), Journal of American Heart Assosiation, 151-153

BPJS, 2014, INA-CBGs Membuat Biaya Kesehatan Lebih Efektif, Info BPJS Kesehatan, 8,34

Dinas Kesehatan Propinsi Yogyakarta. 2017, Profil Kesehatan Propinsi di Yogyakarta Tahun 2017, diakses 9 Oktober 2018, http://www.depkes.go.id/resources/download/profil/PROFIL_KES_PROVINSI_2017/1 4_DIY_2017.pdf

Kementerian Kesehtan Republik Indonesia, 2013, Buku Pegangan Sosialisasi Jaminan Kesehatan Nasional (JKN) dalam Sistem Jaminan Sosial Nasional, 9-10,16,27, Kementerian Kesehatan RI, Jakarta.

Kementerian Kesehatan RI, 2014, Peraturan Menteri Kesehatan Republik Indonesia Nomor 27 Tahun 2014 tentang Petunjuk Teknis Sistem Indonesia Case Base Groups (INA-CBGs), Kementerian Kesehatan RI, Jakarta

Kementerian Kesehatan Republik Indonesia, 2014. Peraturan Menteri Kesehatan Republik Indonesia Indonesia Nomor 28 Tahun 2014 Tentang Pedoman Pelaksanaan Program Jaminan Kesehatan Nasional. Kementerian Kesehatan Republik Indonesia

Kim, T.H., Chun, K.H., Kim., H.J., Han, S.J., Kim, D.J., Kwak, J., Kim, Y.S., Woo, J.T., Park, Y., Nam, M., Baik, S.H., Ahn, K.J., Lee, K.W., 2012. Direct Medical Cost for Patients with Type 2 Diabetes and Related Complications: A Prospective Cohort Study Based on the Korean National Diabetes Program, J. Korean Med. Sci. 27, 876-882. doi: 10.3346/jkms.2012.27.8.876

Lingvay, I., Legendre, J.L., Kaloyanova, P.F., 2009. Insulin-Based Versus Triple Oral Therapy for Newly Diagnosed Type 2 Diabetes. American Diabetes Association. Diabetes Care 32:1789-1795, 200

Malhan, S., Oksuz, E., Babineaux, S.M., Ertekin, A., dan Palmer, J.P., 2014. Assessment of the Direct Medical Costs of Type 2 Diabetes Mellitus and its Complications in Turkey. Turkish Journal of Endocrinology and Metabolism, 18: 39-43.

PERKENI, 2015, Konsensus Pengelolaan dan Pencegahan Diabetes Melitus Tipe 2 di Indonesia 2015, PB. PERKENI, Jakarta.

Watetu, T.A., Beatrice, K.N., Arnold, O., Anselimo M., 2019. Characteristics of Type 2 Diabetes Patients and Their Association with the Metabolic Syndrome and Cardiovascular Risk Factors at Thika Level Five Hospital in Kenya. International Journal of Diabetes and Endocrinology. 4(2): 35-48

World Health Organization (WHO), 2016, Global Report on Diabetes, France: World Health Organization. 
Wu, Y., Ding, Y., Tanaka, Y., Zhang, W., 2014, Risk Factors Contributing to Type 2 Diabetes and Recent Advances in the Treatment and Prevention, International Journal of Medical Sciences, 11 (11), 1185-1200.

Yosmar, R., Almasdy, D., Rahma, F., 2018. Survei Risiko Penyakit Diabetes Melitus Terhadap Masyarakat Kota Padang. Jurnal Sains Farmasi \& Klinis. 134-141.

Zhuo, X., Zhang, P., Hoerger, T.J., 2013, Lifetime Direct Medical Cost of Treating Type 2 Diabetes and Diabetic Complications, American Journal of Preventive Medicine, 45 (3), 253-261 